\title{
Wirulencja populacji Puccinia triticina sprawcy rdzy brunatnej na pszenicy i pszenżycie w Polsce w latach 2016-2017
}

\author{
Virulence of Puccinia triticina the causal agents of wheat and triticale leaf rust in \\ Poland in years 2016-2017
}

\section{Grzegorz Czajowski ${ }^{\varpi}$, Paweł Czembor}

\author{
Zakład Genetyki i Hodowli Roślin \\ Instytut Hodowli i Aklimatyzacji Roślin - PIB w Radzikowie \\ $\triangle$ e-mail: g.czajowski @ihar.edu.pl
}

\begin{abstract}
Badaniami objęto grupę 97 jednozarodnikowych izolatów patogenu, zebranych z różnych odmian pszenicy i pszenżyta na terenie Polski. Analizę wirulencji wykonano w oparciu o zestaw blisko-izogenicznych linii pszenicy, które zawierają pojedyncze, znane geny odporności $L r$. Zaobserwowano, że większość izolatów pochodzących z pszenżyta posiadało wirulencję wobec trzech genów $L r$. Natomiast wśród izolatów pochodzących z pszenicy przeważały izolaty wirulentne wobec innych trzech genów Lr.
\end{abstract}

Słowa kluczowe: pszenica, pszenżyto, rdza brunatna, struktura populacji

The study involved a group of 97 mononuclear pathogen isolates collected from various wheat and triticale cultivars in Poland. The virulence analysis was based on a set of near-isogenic wheat lines that contain single, known $L r$ resistance genes. It was observed that most isolates from triticale had a virulence against three $L r$ genes. On the other hand, isolates derived from wheat predominated virulent isolates against other three $L r$ genes.

Key words: wheat, triticale, leaf rust, population structure

Rdza brunatna pszenicy powodowana przez Puccinia triticina Erikss. jest jedną $\mathrm{z}$ najważniejszych chorób grzybowych pszenicy i pszenżyta. Występuje corocznie z różnym nasileniem uzależnionym od warunków pogodowych. Hodowla i wprowadzanie do uprawy odpornych odmian mogą ograniczyć skutki występowania patogenu. Jednak, aby hodowla odpornościowa była skuteczna, konieczne jest prowadzenie systematycznych badań nad zmianami zachodzącymi w populacji $P$. triticina.

Celem przeprowadzonych badań było określenie struktury populacji $P$. triticina, zachodzących $w$ niej zmian, a także poznanie efektywnych genów odporności.

Badaniami objęto grupę 97 jednozarodnikowych izolatów patogenu, zebranych z różnych odmian pszenicy (48 izolatów) i pszenżyta (49 izolatów) na terenie Polski. Analizę wirulencji wykonano w oparciu o zestaw 37 bliskoizogenicznych linii pszenicy, które zawierają pojedyncze, znane geny odporności $L r$. Jako kontrolę zastosowano wrażliwą odmianę Thatcher.

W populacji pochodzącej z pszenicy wysoką frekwencję wirulencji $(60-100 \%)$ notowano wobec genów: $\operatorname{Lrl}, \operatorname{Lr10}, \operatorname{Lr11}, \operatorname{Lr14a}, \operatorname{Lr} 14 b$, Lr15, Lr16, Lr17, Lr18, Lr21, Lr26, Lr30, Lr33, Lr36, Lr38, Lr44, LrB (RL 6051) i $\operatorname{LrB}(R L$
6061), natomiast niską $(0-30 \%) \mathrm{w}$ stosunku do genów: $L r 2 a, L r 2 b, L r 2 c, L r 23, L r 24, L r 25$, $L r 28, L r 32, L r 52$ i Lr63. Odnotowano znaczny spadek wirulencji wobec genów: $L r 24, L r 29$ i Lr32 w porównaniu do lat ubiegłych. W populacji pochodzącej $\mathrm{z}$ pszenżyta wysoką frekwencję wirulencji obserwowano wobec genów: Lr10, Lr11, Lr14a, Lr14b, Lr18, Lr21, Lr30, Lr33, Lr38, Lr44 LrB (RL 6051) i $L r 64$, podczas gdy niską w przypadku: $L r l, L r 2 a$, Lr3bg, Lr20, Lr23, Lr24, Lr25, Lr28 i LrB (RL 6061). Odnotowano wzrost częstotliwości wirulencji wobec genów: $L r 3, L r 17, L r 25, L r 26$ i obniżenie w przypadku genu $L r 24$ i $L r 29$. Geny $\operatorname{Lr} 9, \operatorname{Lr} 19, \operatorname{Lr} 29$ i $\operatorname{Lr} 52$ były wysoce efektywne na badane izolaty $P$. triticina.

Dla obydwu populacji obliczono złożoność wirulencji. Zaobserwowano, że większość izolatów pochodzących $\mathrm{Z}$ pszenżyta posiadało wirulencję wobec 11, 14 i 16 genów $L r$. Natomiast wśród izolatów pochodzących z pszenicy przeważały izolaty wirulentne wobec 17, 21 i 23 genów $L r$.

Bazując na zestawie 20 linii Thatcher z genami: Lr1, Lr2a, Lr2c, Lr3, Lr3bg, Lr3ka, Lr9, Lr10, Lr11, Lr14a, Lr14b, Lr16, Lr17, Lr18, Lr20, Lr24, Lr26, Lr28, Lr30, LrB (RL 6061) oznaczono 35 patotypów spośród izolatów pochodzących z pszenicy, dominowały patotypy: 
MHTTQ i MHTTS. Obydwa notowano również w populacji z pszenżyta. Pojawily się one także w poprzednich latach badań zarówno wśród patotypów zebranych z pszenicy jak i z pszenżyta.
W populacji patogenu pochodzącej z pszenżyta zidentyfikowano 35 patotypów. $Z$ największą częstotliwością występował patotyp DBHKG, który pojawił się również $\mathrm{w}$ poprzednich latach, $\mathrm{w}$ populacji pochodzącej z pszenżyta.

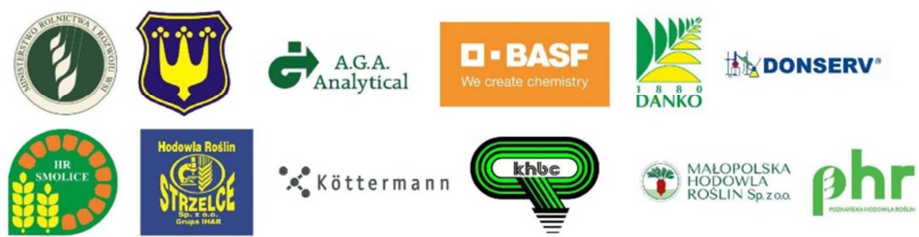

